\title{
Record Efficiencies for EFG and String Ribbon Solar Cells
}

\author{
G. Hahn*,† and P. Geiger \\ Department of Physics, University of Konstanz, PO Box X916, 78457 Konstanz, Germany
}

\begin{abstract}
Solar cells have been processed on Edge-defined Film-fed Growth and String Ribbon silicon. Based on a standard process developed for different types of multicrystalline materials including evaporation of contacts and photolithography for front-contact formation, optimisations have been implemented to deal with the special needs of these low-cost ribbon materials. Especially a remote plasma hydrogenation step and a change from evaporated to screen-printed aluminium back-surface-field improved cell parameters drastically. Independently confirmed stable efficiencies of 16.7\% (EFG) and 17.7\% (String Ribbon) have been achieved on $4 \mathrm{~cm}^{2}$ cells (full area). These values represent the highest stable efficiencies obtained for multicrystalline silicon ribbons so far. Copyright (C) 2003 John Wiley \& Sons, Ltd.
\end{abstract}

\section{INTRODUCTION}

\begin{abstract}
$\mathrm{C}$
rystalline silicon has still by far the largest share of the annual $W_{\mathrm{p}}$ module shipments in the PV market $(88 \%) .{ }^{1}$ Within the last few years a general shift from mono- to multicrystalline $(\mathrm{mc})$ silicon can be observed, with mc-Si now having a 58\% share. This development is mainly due to more cost-effective production, using mc-Si wafers in comparison with high-quality but more expensive mono-Si wafers. Moreover, adapted processing (mainly the implementation of bulk passivation by using hydrogen-rich $\mathrm{SiN}_{x}$ layers as anti-reflective coating (ARC) in combination with a firing step) led to higher efficiencies for mc-Si in industrial processes. But the standard cast mc-Si wafer still contributes up to $50 \%$ of the total module cost, ${ }^{2}$ mainly because cost-intensive ingot casting and subsequent sawing steps are involved. With the standard cast ingot methods, about $60 \%$ of the silicon material is wasted during wafer production, ${ }^{3}$ this being the main reason for the high share of the wafer costs.

Ribbon silicon is a promising alternative to bring down wafer costs, as the wafer crystallises directly out of the melt in the required thickness. The materials under investigation in this study have some similarities. Edgedefined Film-fed Growth (EFG) silicon from RWE Schott Solar ${ }^{4}$ has been produced commercially since 1994, Evergreen Solar's String Ribbon (SR) ${ }^{5}$ was commercialised in 2001. Both materials are grown vertically out of the melt ${ }^{6}$ with a pulling speed of $1-2 \mathrm{~cm} / \mathrm{min}$ and a thickness of about $300 \mu \mathrm{m}$. Owing to the different shape of the meniscus at the solid/fluid interface and the lack of a shaping dye, SR can tolerate higher temperature
\end{abstract}

\footnotetext{
* Correspondence to: G. Hahn, Department of Physics, University of Konstanz, PO Box X916, 78457 Konstanz, Germany.

${ }^{\dagger}$ E-mail: giso.hahn@uni-konstanz.de

Contract/grant sponsor: German BMWi within the KoSi and ASiS projects; contract/grant number: 0329858J/8; 0329846J.
} 
fluctuations, whereas EFG has a higher throughput as a closed octagon with eight 'sheets' (width $10 \mathrm{~cm}$ ) is grown. In the case of SR, two strings provide edge stabilisation (width of the silicon sheet $8 \mathrm{~cm}$ ). The interstitial oxygen concentration for both materials is low $\left(<5 \times 10^{16} \mathrm{~cm}^{-3}\right)$, the substitutional carbon concentration is higher in EFG $\left(10^{18} \mathrm{~cm}^{-3}\right)$ than in SR $\left(6 \times 10^{17} \mathrm{~cm}^{-3}\right)$. The as-grown material quality for both materials $(p$ type with bulk resistivities of about $3 \Omega \mathrm{cm}$ ) is quite inhomogeneous with minority-carrier bulk lifetimes between 0.5 and $50 \mu \mathrm{s}$ within one wafer. Dislocation densities vary between $10^{4}$ and $10^{6} \mathrm{~cm}^{-2}$ within several grains, which can cover an area of several $\mathrm{cm}^{2}$. In previous studies ${ }^{7-10}$ it was shown that lifetimes can be enhanced significantly during cell processing by P- and Al-gettering as well as hydrogenation.

\section{STANDARD PROCESSING}

In this study we have chosen a process that includes evaporation of contacts and photolithography for frontcontact formation to minimise grid shadowing losses and to get a good blue response of the solar cells. Based on our standard process used for mc-Si materials (Figure 1), we optimised single processing steps to the specific needs of the materials. The standard process consisted of an acidic etching step ( $5 \mu \mathrm{m}$ per side in a modified CP6 etch), a $\mathrm{POCl}_{3}$ diffusion in an open-tube furnace ( $90 \Omega /$ square) with subsequent etching of the P-glass, the thermal growth of a 10 to $15 \mathrm{~nm}$ thick oxide followed by an Al-gettering step at $800^{\circ} \mathrm{C}$ for $30 \mathrm{~min}(2 \mu \mathrm{m} \mathrm{Al} \mathrm{evaporated} \mathrm{on}$ the back surface, etched off after gettering). The gettering step simultaneously eliminates the rear-surface emitter. The Ti/Pd/Ag front contact was evaporated $(50 \mathrm{~nm} / 50 \mathrm{~nm} / 3 \mu \mathrm{m})$ by photolithography followed by evaporation of a $2 \mu \mathrm{m} \mathrm{Al}$ back contact which covers the whole back surface. Edge isolation was performed by dicing four $2 \times 2 \mathrm{~cm}^{2}$ cells out of the processed $5 \times 5 \mathrm{~cm}^{2}$ wafers. By doing so we end up with full-area cells, so the cells have an open $p n$ junction at the edges, which reduces fill factor and open-circuit voltage compared with buried $p n$ junctions used in other processes. Afterwards, the cells without any surface texture or ARC have been characterised by $I V$ measurements with the total area of the cell being illuminated (no metallisation masking).

\begin{tabular}{|c|c|c|}
\hline $\begin{array}{c}\text { Process A } \\
\text { standard process }\end{array}$ & $\begin{array}{c}\text { Process B } \\
\text { Al screen printing (SP) }\end{array}$ & $\begin{array}{c}\text { Process C } \\
\text { Al-gettering + SP }\end{array}$ \\
\hline & & Acidic etching \\
\hline & & Al-gettering \\
\hline Acidic etching & Acidic etching & \\
\hline P-Diffusion $(90 \Omega / s q)$ & P-Diffusion $(90 \Omega / s q)$ & P-Diffusion $(90 \Omega / s q)$ \\
\hline Thermal oxidation & Thermal oxidation & Thermal oxidation \\
\hline Al-gettering & Al screen printing + firing & Al screen printing + firing \\
\hline Photolithography & Photolithography & Photolithography \\
\hline $\mathrm{Ti} / \mathrm{Pd} / \mathrm{Ag}$ front contact & $\mathrm{Ti} / \mathrm{Pd} / \mathrm{Ag}$ front contact & $\mathrm{Ti} / \mathrm{Pd} / \mathrm{Ag}$ front contact \\
\hline \multirow[t]{2}{*}{ Al back contact } & Al back contact & Al back contact \\
\hline & Ag electroplating & Ag electroplating \\
\hline Cell separation & Cell separation & Cell separation \\
\hline IV measurement & IV measurement & IV measurement \\
\hline MIRHP passivation & MIRHP passivation & MIRHP passivation \\
\hline IV measurement & IV measurement & IV measurement \\
\hline
\end{tabular}

Figure 1. Schematic overview of the processes applied in this study. Standard process (A) as used for mc-Si materials (including optimised MIRHP step); process B introduces screen-printed Al BSF and additional electroplating of Ag front contact; in process $\mathrm{C}$ an additional $\mathrm{Al}$ gettering step is included, identical to that used in process $\mathrm{A}$ prior to cell processing 


\section{H PASSIVATION}

The effect of bulk passivation of crystal defects by atomic hydrogen has been studied extensively both on EFG and SR in several studies. ${ }^{7-10}$ In our study we have chosen microwave-induced remote hydrogen plasma (MIRHP) passivation ${ }^{11}$ which has proven to work excellently in passivating defects in ribbon silicon. ${ }^{12,13}$ The passivation step was applied after the initial $I V$ measurement; in this way the effect of hydrogenation can be quantified on cell parameter level. Therefore, a second $I V$ measurement was carried out after hydrogenation. For standard cast mc-Si materials the passivation is normally at $350^{\circ} \mathrm{C}$ for $60 \mathrm{~min} .{ }^{14}$

For low-oxygen materials, such as EFG and SR, the diffusion of hydrogen into the bulk of the wafer as well as the diffusion out of the wafer is much faster than for materials with a higher concentration of interstitial oxygen. ${ }^{14,15}$ Therefore the passivation temperature must be lowered in order to keep the hydrogen within the bulk. This is even more important as no capping layer prevents the hydrogen from diffusing out through the front surface at elevated temperatures (no ARC). The optimised MIRHP step with hydrogenation at $320^{\circ} \mathrm{C}$ for 60 min was implemented in the standard process of this study.

\section{OPTIMISATION}

\section{Electroplating}

An investigation of series resistance losses within the evaporated $3 \mu \mathrm{m}$ thick front grid led to the conclusion that fill factors can be slightly improved if a silver electroplating step is carried out after evaporation of the front contact. The thickness of the evaporated Ag was therefore reduced to $50 \mathrm{~nm}$, followed by additional Ag electroplating of $7 \mu \mathrm{m}$.

\section{Back-surface-field and back-surface recombination velocity}

The evaporated Al used for gettering within the standard process results in a back-surface-field (BSF) thickness of $<1 \mu \mathrm{m}$, giving a back-surface recombination velocity $S_{\mathrm{b}}$ of about $1500 \mathrm{~cm} / \mathrm{s}$. As lifetimes in EFG and SR can locally be as high as $300 \mu \mathrm{s}^{16}$ (corresponding to diffusion lengths of $>700 \mu \mathrm{m}$ ), $S_{\mathrm{b}}$ has a severe impact on both short-circuit current density $J_{\mathrm{sc}}$ and open-circuit voltage $V_{\mathrm{oc}}$. To reduce $S_{\mathrm{b}}$, a thicker Al BSF would be beneficial. Therefore we have chosen screen printing of Al paste (thickness about $40 \mu \mathrm{m}$ ) followed by a short firing step for BSF formation (BSF thickness approximately 6-8 $4 \mathrm{~m}$ ). In addition, this method has the advantage that screen printing is the standard metallization technique used in industry for large-scale and cost-effective production, therefore reducing complexity of the applied process.

On the other hand the reduced gettering time of $<1 \mathrm{~min}$ at relevant temperatures $>600^{\circ} \mathrm{C}$, compared with $30 \mathrm{~min}$ for the standard process, might show an only minor gettering efficiency. Therefore we were interested to figure out the impact of the different Al gettering steps on solar cell level. To quantify the effect of the longer $\mathrm{Al}$ gettering step used in the standard process, we split 'neighbouring' wafers (adjacent wafers in the direction of pulling with similar crystal grain structures) in pairs. One-half of the wafers underwent the standard Al gettering step of the standard process $\left(2 \mu \mathrm{m} \mathrm{Al}\right.$ evaporated at the back surface, gettering time $30 \mathrm{~min}$ at $\left.800^{\circ} \mathrm{C}\right)$ before $\mathrm{POCl}_{3}$ diffusion (process $\mathrm{C}$ in Figure 1). The $\mathrm{Al}$ layer was etched off; from that stage on wafers were processed in parallel as shown in Figure 1 (processes $\mathrm{B}$ and $\mathrm{C}$ ) according to the optimised processing sequences.

\section{RESULTS}

Approximately 25 cells for each material and process outlined in Figure 1 have been fabricated from standard quality material (no selection prior to processing). The positive influence of hydrogenation could be seen for all processes under investigation. As recombination in the base and the space charge region is reduced, all cell parameters increase significantly. Parameters shown in Table I refer to the best cells of each given process 
Table I. IV parameters of the best EFG and SR cells $\left(4 \mathrm{~cm}^{2}\right)$ fabricated according to the processes shown in Figure 1 before and after hydrogenation

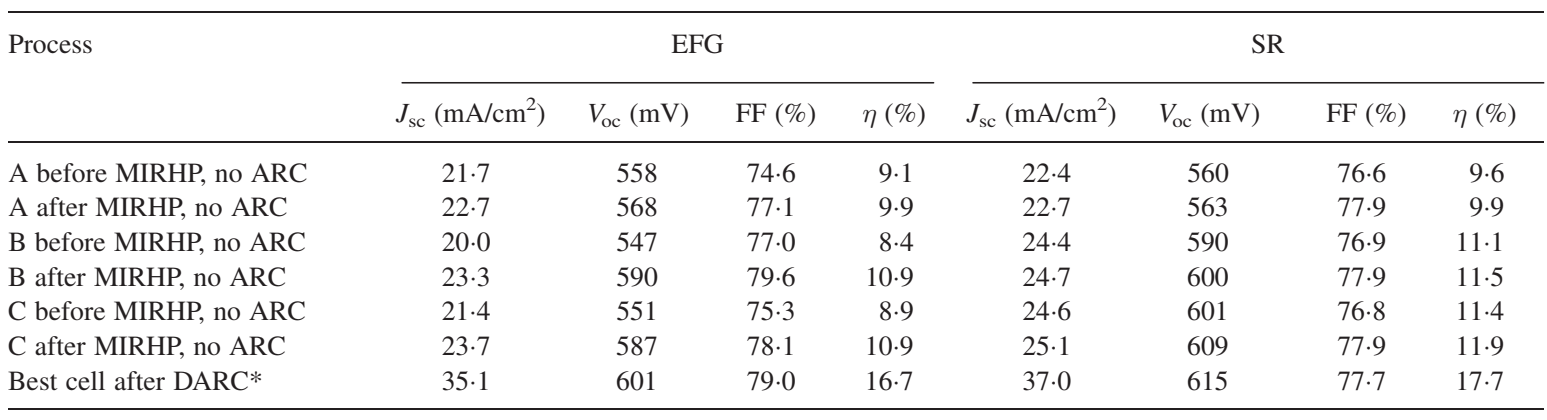

*Parameters of the best cells after DARC have been independently confirmed at JRC Ispra.

before and after hydrogenation. As the standard deviation for cells processed according to one of the schemes in Figure 1 is larger than the variations between the mean values of the different processes, a reliable conclusion cannot be drawn by comparison of these mean values alone. To overcome this problem, a larger statistic would be needed or adjacent wafers have to be compared.

Assuming that within EFG or SR the best cells of each process are of comparable material quality, it can be seen that the introduction of the screen-printed BSF in process B increases both $V_{\mathrm{oc}}$ and $J_{\mathrm{sc}}$ significantly in comparison with the standard process. The BSF formed by screen printing is estimated to give values for $S_{\mathrm{b}}$ in the range of $200 \mathrm{~cm} / \mathrm{s}$ as compared with about $1500 \mathrm{~cm} / \mathrm{s}$ for evaporated $\mathrm{Al}$ in the standard process.

The shorter gettering step in process B did not affect efficiency of the best cells significantly, as can be deduced by comparing the results from processes B and C. However, by comparing adjacent wafers, slight improvements due to the additional gettering step can be observed, as shown in Figure 2. A more detailed analysis of the experimental data concerning the additional $\mathrm{Al}$ gettering step will be carried out in the future.

A $\mathrm{ZnS} / \mathrm{MgF}_{2}$ double-layer ARC was deposited on the best EFG and SR cell. The parameters of these cells have been independently confirmed at JRC Ispra (Table I). The efficiencies obtained on EFG (16.7\%) as well as
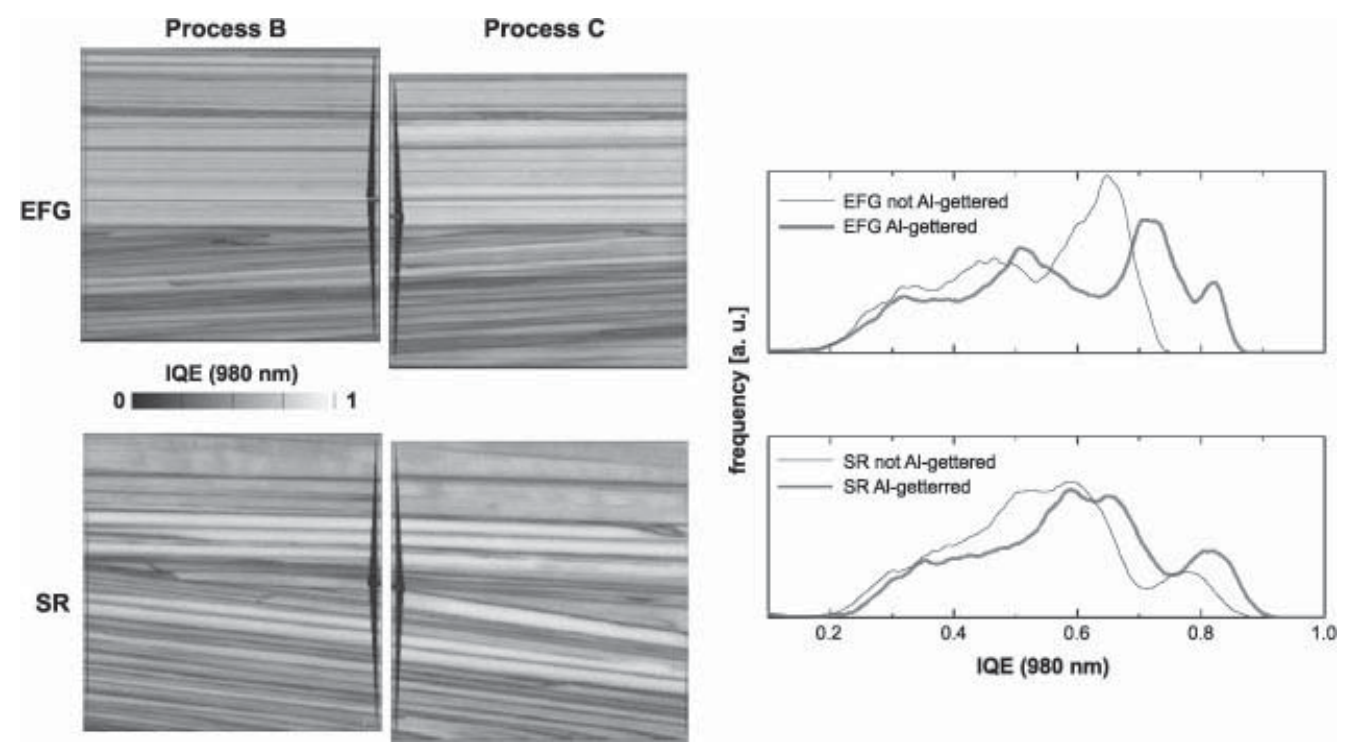

Figure 2. Mapped IQEs at $980 \mathrm{~nm}$ of adjacent cells fabricated according to process B (no additional $\mathrm{Al}$ gettering) and process $\mathrm{C}$ (additional Al gettering step prior to cell process). For both materials slight improvements due to the additional gettering step are visible in the histograms of the IQE at $980 \mathrm{~nm}$ 


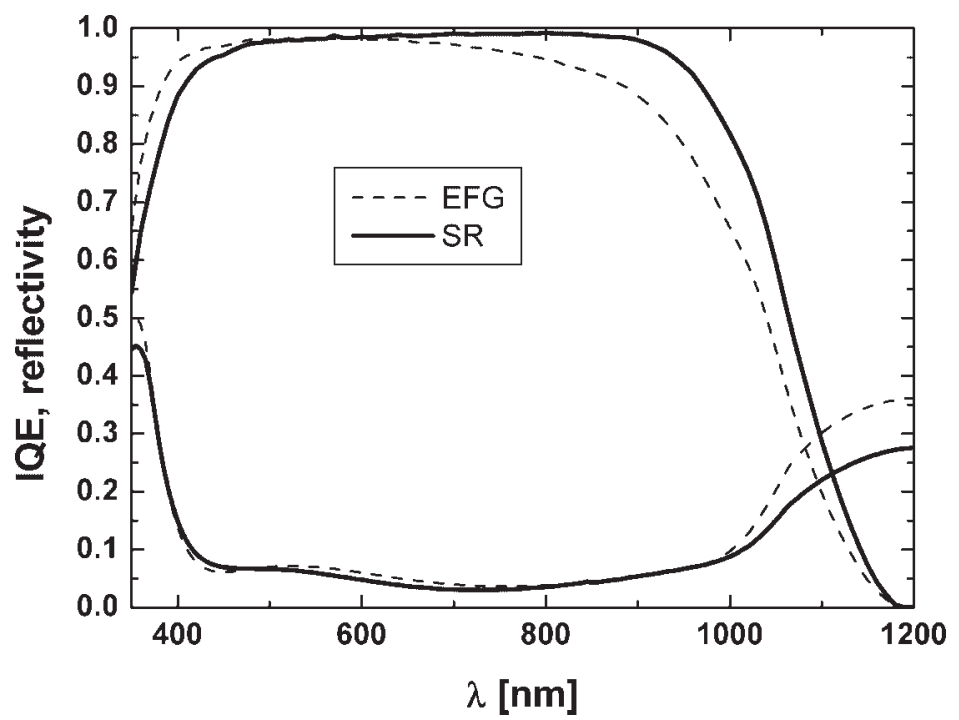

Figure 3. IQE and reflectivity data for the best EFG and SR cell after DARC deposition
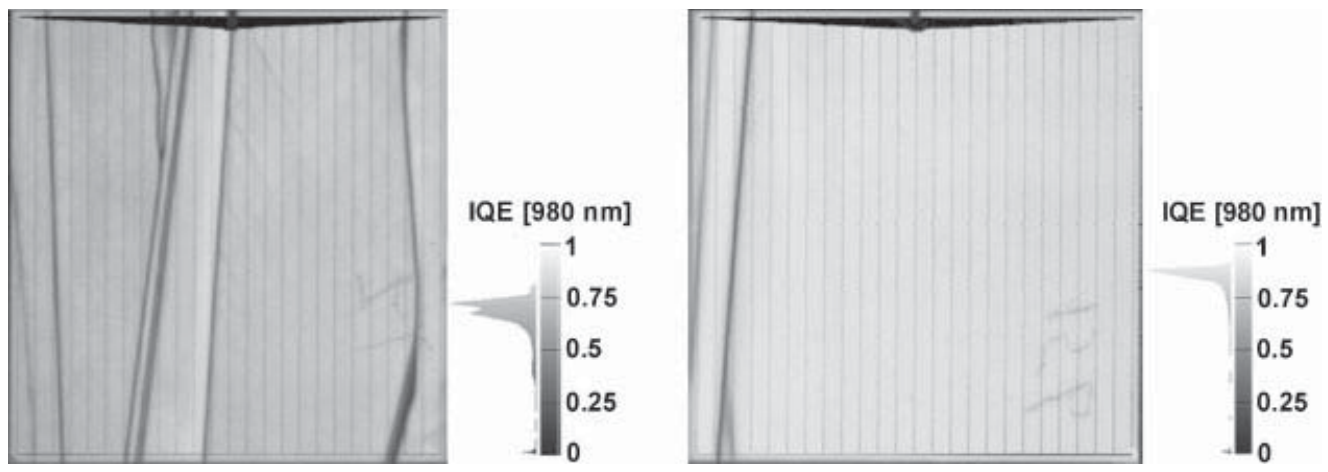

Figure 4. IQE mappings at $980 \mathrm{~nm}$ of the best EFG (left, process B) and SR (right, process C) cell after DARC deposition. Both cells include several electrically active grain boundaries

SR $(17.7 \%)$ represent the highest stable values (12 h illumination, $1 \mathrm{sun}$ ) reached for these materials, with the value of the SR cell being the highest obtained for mc-Si ribbon material. In Figure 3 internal quantum efficiencies (IQE) and reflectivities of these two cells are shown. Some grain boundaries remain electrically active in the processed solar cells, as can be seen in the mapped IQEs at $980 \mathrm{~nm}$ in Figure 4.

To increase efficiencies further, more complex cell processes could be applied. A surface texture would result in less reflection, a buried $p n$ junction can increase both fill factor and open-circuit voltage.

\section{Acknowledgements}

We wish to thank M. Keil for technical assistance during cell processing and A. Gabor from Evergreen Solar Inc. as well as A. Metz from RWE Schott Solar for material supply and stimulating discussions. Part of this work was financed by the German BMWi within the KoSi and ASiS projects under contracts 0329858J/8 and $0329846 \mathrm{~J}$. 


\section{REFERENCES}

1. Maycock PD. PV News 2003; 22(3): 1-5.

2. Maycock PD. PV Technology, Performance, and Cost: 1995-2010. PV Energy Systems Inc., Warrenton, $2002 ; 103$. Available at pvenergy.com

3. Sarti D, Einhaus R. Silicon feedstock for the multi-crystalline photovoltaic industry. Solar Energy Materials and Solar Cells 2002; 72: 27-40.

4. Wald FV. In Crystals: Growth, Properties and Applications 5, Grabmaier J (ed.). Springer: Berlin, 1981; 147-198.

5. Sachs WM, Ely D, Serdy J. Edge stabilized ribbon (ESR) growth of silicon for low cost photovoltaics. Journal of Crystal Growth 1987; 82: 117-121.

6. Kalejs JP. Silicon ribbons and foils_-state of the art. Solar Energy Materials and Solar Cells 2002; 72: 139-153.

7. Jeong J-W, Rohatgi A, Rosenblum MD, Kalejs JP. Lifetime enhancement in EFG multicrystalline silicon. Proceedings of the 28th IEEE PVSC, Anchorage, 2001; 83-86.

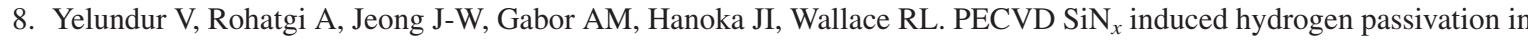
string ribbon silicon. Proceedings of the 28th IEEE PVSC, Anchorage, 2001; 91-94.

9. Geiger P, Hahn G, Fath P, Bucher E. Spatially resolved lifetime investigations of Al- and P-gettering in combination with remote hydrogen plasma passivation in EFG ribbon silicon, Proceedings of the 17th EC PVSEC, Munich, 2001; $1715-1718$.

10. Geiger P, Hahn G, Fath P, Bucher E. Lifetime enhancement in string ribbon silicon - a study based on spatially resolved measurements. Proceedings of the 17th EC PVSEC, Munich, 2001; 1754-1756.

11. Spiegel M, Fath P, Peter K, Buck B, Willeke G, Bucher E. Detailed study on microwave induced remote hydrogen plasma passivation of multicrystalline silicon. Proceedings of the 13th EC PVSEC, Nizza, 1995; 421-424.

12. Spiegel M, Hahn G, Jooss W, Keller S, Fath P, Willeke G, Bucher E. Investigation of hydrogen diffusion, effusion and passivation in solar cells using different multicrystalline silicon base materials. Proceedings of the 2nd WC PVSEC, Vienna, 1998; 1685-1688.

13. Hahn G, Geiger P, Fath P, Bucher E. Hydrogen passivation of ribbon silicon-electronic properties and solar cell results, Proceedings of the 28th IEEE PVSC, Anchorage, 2001; 95-98.

14. Hahn G, Jooss W, Spiegel M, Fath P, Willeke G, Bucher E. Improvement of mc Si solar cells by Al-gettering and hydrogen passivation. Proceedings of the 26th IEEE PVSC, Anaheim, 1997; 75-78.

15. Pernau T, Hahn G, Spiegel M, Dietsche G. Bulk hydrogenation of mc silicon materials and solar cells: from research lab to PV industry. Proceedings of the 17th EC PVSEC, Munich, 2001; 1764-1767

16. Geiger P, Kragler G, Hahn G, Fath P, Bucher E. Spatially resolved lifetimes in EFG and string ribbon silicon after gettering and hydrogenation steps, Proceedings of the 29th IEEE PVSC, New Orleans, 2002; 186-189. 